\title{
A New High-Pressure Phase Transition in Natural Gedrite
}

\author{
Tommy Yong ${ }^{1}{ }^{(}$, Craig R. Bina ${ }^{2}$, Gregory J. Finkelstein ${ }^{1} \mathbb{(}$, Dongzhou Zhang ${ }^{1}$ and \\ Przemyslaw Dera ${ }^{1, *(1)}$ \\ 1 Hawaii Institute of Geophysics and Planetology, School of Ocean and Earth Science and Technology, \\ University of Hawaii at Manoa, Honolulu, HI 96822, USA; tyong@hawaii.edu (T.Y.); \\ gjfinkel@hawaii.edu (G.J.F.); dzhang@hawaii.edu (D.Z.) \\ 2 Department of Earth and Planetary Sciences, Northwestern University, Evanston, IL 60201, USA; \\ craig@earth.northwestern.edu \\ * Correspondence: pdera@hawaii.edu; Tel.: +(808)-956-6347
}

Received: 23 September 2019; Accepted: 9 October 2019; Published: 11 October 2019

\begin{abstract}
High-pressure diamond-anvil cell synchrotron X-ray diffraction experiments were conducted on single-crystal samples of natural orthoamphibole; gedrite; with composition; $\left(\mathrm{K}_{0.002} \mathrm{Na}_{0.394}\right)\left(\mathrm{Mg}_{2}\right)\left(\mathrm{Mg}_{1.637} \mathrm{Fe}_{2.245} \mathrm{Mn}_{0.004} \mathrm{Ca}_{0.022} \mathrm{Cr}_{0.003} \mathrm{Na}_{0.037} \mathrm{Al}_{1.052}\right)\left(\mathrm{Si}_{6.517} \mathrm{Al}_{1.483}\right) \mathrm{O}_{22}(\mathrm{OH})_{2}$. The samples were compressed at $298 \mathrm{~K}$ up to a maximum pressure of 27(1) GPa. In this pressure regime, we observed a displacive phase transition between 15.1(7) and 21(1) GPa from the orthorhombic Pnma phase to a new structure with space group $\mathrm{P} 2{ }_{1} / \mathrm{m}$; which is different from the familiar $P 2_{1} / m$ structure of cummingtonite and retains the $(+,+,-,-)$ I-beam stacking sequence of the orthorhombic structure. The unit cell parameters for the new phase at 21(1) GPa are $a=17.514(3), b=17.077(1), c=4.9907(2) \AA$ and $\beta=92.882(6)^{\circ}$. The high-pressure $P 2_{1} / m$ phase is the first amphibole structure to show the existence of four crystallographically distinct silicate double chains. The orthorhombic to monoclinic phase transition is characterized by an increase in the degree of kinking of the double silicate chains and is analogous to displacive phase changes recently reported in orthopyroxenes, highlighting the parallel structural relations and phase transformation behavior of orthorhombic single- and double-chain silicates.
\end{abstract}

Keywords: amphibole; phase transition; high-pressure; single-crystal X-ray diffraction; diamond anvil cell; synchrotron source

\section{Introduction}

The amphibole crystal structure is characterized by double chains of silicate tetrahedra that extend along the [001] crystallographic direction. A band of octahedrally coordinated cations, in orthoamphiboles designated by sites M1, M2, M3, and M4, link adjacent chains of silicate tetrahedra, T1A, T1B, T2A and T2B, along the [100] direction. In clinoamphibole structure, there are only two symmetry-independent tetrahedral sites. The site symmetries of M1, M2, M3 and M4 are 1, 1, $\mathrm{m}$ and 1, respectively. In the Pnma amphibole structure, there are two distinct types of double-silicate chains, the A-chain and B-chain. The structure and crystal chemical relations of amphibole group minerals have been well documented [1-4].

Gedrite, with ideal formula $\mathrm{Mg}_{2}\left(\mathrm{Mg}_{3} \mathrm{Al}_{2}\right)\left(\mathrm{Si}_{6} \mathrm{Al}_{2}\right) \mathrm{O}_{22}(\mathrm{OH})_{2}$, is the aluminous end-member of the anthophyllite-gedrite orthoamphibole solid solution. It is among the most crystal-chemically complex amphiboles and occurs in metamorphic rocks, including low-Ca metabasites and orthoamphibole-cordierite gneisses [5,6]. Two main coupled substitutions are generally present in gedrites, the first is the substitution of $\mathrm{Na}^{+}$for vacancy in the A-site coupled with the substitution of $\mathrm{Al}^{3+}$ for $\mathrm{Si}^{4+}$ in the T-sites; the second is the substitution of $\mathrm{Al}^{3+}$ for $\mathrm{Mg}^{2+}$ in the M-sites coupled with 
substitution of $\mathrm{Al}^{3+}$ for $\mathrm{Si}^{4+}$ in the T-sites. The complex nature of gedrites makes them a model structure for understanding high-pressure crystal-chemical relationships and the effects of composition on thermodynamic properties. Knowledge of the non-ambient behavior of gedrites will provide valuable information in modeling various petrological and geophysical processes within the Earth's interior, such as partial melting due to dehydration reactions and water transport to the mantle. At ambient pressure, gedrite was found to transform to a new synthetic amphibole 'oxo-gedrite' at $973 \mathrm{~K}$, indicating dehydrogenation of the gedrite structure [7].

The crystallographic, physical and chemical similarities between amphiboles and pyroxenes have been recognized since the 1930s [8-10]. Refs. [11-13] showed that orthopyroxenes undergo a series of phase transformations with increasing pressure from orthorhombic to monoclinic (but preserving orthopyroxene stacking) and back to orthorhombic symmetry. Due to the similarities between amphiboles and pyroxenes, it can be hypothesized that an analogous series of phase transformations exists in orthoamphiboles. Previous high-pressure studies on orthorhombic amphiboles are limited to compressibility measurements up to $7 \mathrm{GPa}$ and no phase transformations were observed $[14,15]$. Until now, the high-pressure phase transformation behavior of orthorhombic amphiboles has been unknown [16]. In this study, we report the observations of a new phase transition in natural gedrite, which takes place between 15.1(7) and 21(1) GPa, and leads from Pnma (gedrite) to $P 2_{1} / m$ ( $\beta$-gedrite) symmetry.

\section{Materials and Methods}

In this study, we used a natural gedrite crystal from Karelien, Russia, with composition $\left(\mathrm{K}_{0.002} \mathrm{Na}_{0.394}\right)\left(\mathrm{Mg}_{2}\right)\left(\mathrm{Mg}_{1.637} \mathrm{Fe}_{2.245} \mathrm{Mn}_{0.004} \mathrm{Ca}_{0.022} \mathrm{Cr}_{0.003} \mathrm{Na}_{0.037} \mathrm{Al}_{1.052}\right)\left(\mathrm{Si}_{6.517} \mathrm{Al}_{1.483}\right) \mathrm{O}_{22}(\mathrm{OH})_{2}$ determined by wavelength-dispersive spectrometry (WDS) using a JEOL Hyperprobe JXA-8500F at $15 \mathrm{keV}$. The composition was determined through the average of twelve spot analyses. The samples were compositionally homogeneous with no zoning, as evidenced by the electron backscattered image. All iron was assigned as $\mathrm{Fe}^{2+}$ to maintain charge balance; however, the presence of trace amounts of $\mathrm{Fe}^{3+}$ is a possibility. The results from the microprobe analysis are shown in Table 1 . The chemical formula was calculated based on $23 \mathrm{O}$ atoms as described by Ref. [4]. This calculation assumes that $(\mathrm{O}, \mathrm{OH}, \mathrm{F}, \mathrm{Cl})=2$ apfu, and since no $\mathrm{F}$ and $\mathrm{Cl}$ were detected from the microprobe analysis, we determine there were 2 apfu of $\mathrm{OH}$.

To characterize the ambient-pressure crystal structure of the sample used in the high-pressure experiments, a euhedral crystal platelet $(0.15 \times 0.09 \times 0.02 \mathrm{~mm})$ was selected and mounted on a Bruker D8 Venture single crystal diffractometer with a Ag I $\mu$ S microfocus source $(0.56089 \AA)$ and PHOTON-II CPAD detector at the University of Hawaii at Manoa's X-ray Atlas Diffraction Laboratory. The X-ray diffraction data were collected over a $\theta$ range from $2.502^{\circ}$ to $30.733^{\circ}$ with $98.9 \%$ completeness. Least-squares structure refinement was done with the program SHELXL2014 [17]. The initial structure model (American Mineralogist Crystal Structure Database code 0000215) of gedrite from Ref. [1] was used. All atoms were refined using anisotropic atomic displacement parameters, except for hydrogen. Hydrogen atom positions were located from the difference Fourier map and then refined using a restraint on the oxygen-hydrogen distance. To the best of our knowledge, hydrogen atom positions in gedrite have not been reported in the literature before. Details on hydrogen-bond and intermolecular contact interaction geometry in the ambient gedrite phase are reported in the Supplementary Table S1.

Full occupancy was assumed for all sites except the A site, which was constrained to match the calculated chemical formula from the microprobe analysis. The structure was refined using the chemical formula determined from the microprobe analysis as a restraint; however, small amounts of $\mathrm{K}$ in the $\mathrm{A}$ site ( $<0.4$ electrons per unit cell) and $\mathrm{Mn}, \mathrm{Ca}, \mathrm{Cr}$ and $\mathrm{Na}$ in the $\mathrm{M}$ sites ( $\sim 1$ electron total contribution per unit cell) were ignored, as $\mathrm{X}$-ray diffraction cannot resolve these small compositional differences. In our refined model, the M1, M3, and M4 sites were only occupied by $\mathrm{Mg}^{2+}$ and $\mathrm{Fe}^{2+}$, the $\mathrm{M} 2$ site was occupied by $\mathrm{Al}^{3+}, \mathrm{Mg}^{2+}$ and $\mathrm{Fe}^{2+}$, the T1A, T1B and T2B were occupied by both $\mathrm{Si}^{4+}$ and $\mathrm{Al}^{3+}$, and the T2A site only contained $\mathrm{Si}^{4+}$. Determination of site occupancies was done following [1]; after assigning all ${ }^{\mathrm{VI}} \mathrm{Al}^{3+}$ content to the $\mathrm{M} 2$ site, we refined the $\mathrm{Fe}^{2+}$ and $\mathrm{Mg}^{2+}$ portion for the remaining portion of the 
M2 site, as well as the M1, M3 and M4 sites. Additionally, previous studies of gedrite have shown that there is a strong preference for octahedrally coordinated $\mathrm{Al}^{3+}$ at the $\mathrm{M} 2$ site $[18,19]$. The determined site occupancies of the four $\mathrm{M}$ sites and four $\mathrm{T}$ sites are: $\mathrm{M} 1$ : $\mathrm{Mg}^{2+}=0.771(4), \mathrm{Fe}^{2+}=0.228(4)$; $\mathrm{M} 2: \mathrm{Al}^{3+}=0.541(4), \mathrm{Mg}^{2+}=0.401(5), \mathrm{Fe}^{2+}=0.055(4) ; \mathrm{M} 3: \mathrm{Mg}^{2+}=0.747(6), \mathrm{Fe}^{2+}=0.252(6)$; $\mathrm{M} 4$ : $\mathrm{Mg}^{2+}=0.287(4), \mathrm{Fe}^{2+}=0.712(4) ; \mathrm{T} 1 \mathrm{~A}: \mathrm{Si}^{4+}=0.74(7), \mathrm{Al}^{3+}=0.25(7) ; \mathrm{T} 1 \mathrm{~B}: \mathrm{Si}^{4+}=0.60(7), \mathrm{Al}^{3+}=0.39(7) ;$ T2A: $\mathrm{Si}^{4+}=1.0 ; \mathrm{T} 2 \mathrm{~B}: \mathrm{Si}^{4+}=0.90(7), \mathrm{Al}^{3+}=0.09(7)$ Based on these values, our refined chemical formula is $\left(\mathrm{Na}_{0.393}\right)\left(\mathrm{Mg}_{2}\right)\left(\mathrm{Mg}_{1.665} \mathrm{Fe}_{2.242} \mathrm{Al}_{1.082}\right)\left(\mathrm{Si}_{6.48} \mathrm{Al}_{1.46}\right) \mathrm{O}_{22}(\mathrm{OH})_{2}$, which is in good agreement with our chemical formula obtained by electron microprobe analysis.

In-situ high-pressure diffraction experiments were conducted at beamline 13BM-C (GSECARS) of the Advanced Photon Source, Argonne National Laboratory [20]. The experiment consisted of six compression measurements at 1.84(9), 4.3(2), 10.6(5), 15.1(7), 21(1) and 27(1) GPa and seven decompression measurements at 24(1), 22(1), 20(1), 15.8(8), 14.2(7), 6.1(3) and 4.0(2) GPa. Two crystals of gedrite with an approximate size of $0.065 \times 0.0030 \times 0.005 \mathrm{~mm}$ were loaded into a four-pin diamond-anvil cell (DAC) with $300 \mu \mathrm{m}$ culet diamonds. The crystals were mounted in the DAC in different orientations to allow for more coverage of reciprocal space. Conical anvils and backing plates were used to increase the coverage of reciprocal space [21]. The sample chamber consisted of a hole $0.185 \mathrm{~mm}$ in diameter that was drilled through a $0.250 \mathrm{~mm}$ thick rhenium gasket preindented to a thickness of $0.040 \mathrm{~mm}$. In addition to the sample crystals, two small ruby spheres were placed in the sample chamber as pressure calibrants. The pressure was calculated from the shift of the R1 ruby fluorescence line [22]. The DAC was gas-loaded at the GSECARS-COMPRES facility with neon as the pressure medium. Neon is hydrostatic below $4.7 \mathrm{GPa}$ and quasihydrostatic to $78 \mathrm{GPa}$ [23-26]. After gas-loading, the cell was at $\sim 1.79 \mathrm{GPa}$ and the sample chamber had shrunk to $\sim 0.133 \mathrm{~mm}$ in diameter. Ruby fluorescence spectra were measured at each pressure point both before and after the X-ray data collection. The reported pressures were obtained after each X-ray measurement. Uncertainties in pressures were taken as $5 \%$ of the pressure measurement.

High-pressure diffraction experiments were performed using a monochromatic $X$-ray beam with an energy of $28.6 \mathrm{keV}(0.434 \AA)$, and bandwidth of $1 \mathrm{eV}$, that was focused with a Kirkpatrick-Baez mirror system to a spot of $0.012 \mathrm{~mm}(\mathrm{H}) \times 0.018 \mathrm{~mm}(\mathrm{~V})$, as measured at full-width at half-maximum (FWHM). The MAR165 charge-coupled device (CCD) detector was placed roughly $180 \mathrm{~mm}$ away from the sample, and $\mathrm{LaB}_{6}$ powder was used to calibrate the distance and tilting of the detector. The sample was placed at the rotation center of the diffractometer and aligned using an optical microscope. A total angular range from $\varphi=57^{\circ}$ to $123^{\circ}$ (total angular opening of $\pm 33^{\circ}$ ) was covered during the scans. A series of step and wide-step $\varphi$-exposures were collected. Step scans involved $1^{\circ}$ angular increments, while wide-step scans had $6.6^{\circ}$ angular increments. The exposure time was at $5 \mathrm{sec} /{ }^{\circ}$. After collection of step and wide-step $\varphi$-exposures at the zero detector position, more wide-step $\varphi$-exposures were recorded with the detector rotated about its horizontal axis $(2 \theta)$ by $20^{\circ}$ and then, with the detector rotated about the vertical axis $(v)$ by $10^{\circ}$ and $-10^{\circ}$. Exposure time for the non-zero detector position was at $10 \mathrm{sec} /{ }^{\circ}$. At $21(1) \mathrm{GPa}$, the exposure time was increased to $10 \mathrm{sec} /{ }^{\circ}$ for the zero detector position and $20 \mathrm{sec} /{ }^{\circ}$ for non-zero positions.

Step $\varphi$-exposures (13BM-C) were used in reconstruction of the crystal's reciprocal lattice to determine the unit cell parameters and to index the diffraction pattern. Wide-step $\varphi$-exposures were used to determine d-spacings, azimuthal angles around the beam center and peak intensities of each diffraction peak in order to solve the crystal structure. Data collection was performed following the procedure described by Refs. [27,28], and analyzed using the GSE_ADA/RSV program [28]. Integrated peak intensities were corrected for Lorenz, polarization, DAC absorption and sample displacement effects using the methods implemented in GSE_ADA. Because of the high incident energy, low absorption coefficient, and negligible sample thickness, the effects of sample absorption were ignored. The linear absorption coefficient at 10.6(5) GPa was $0.751 \mathrm{~mm}^{-1}$ and at 21(1) GPa was $0.807 \mathrm{~mm}^{-1}$. Based on these values and our sample thickness of $0.005 \mathrm{~mm}$, the estimated attenuation of X-ray intensity is less than $1 \%$. 
The high-pressure structure at 21(1) GPa was solved by converting the Pnma structure model, refined at 10.6(5) GPa before the transition, to the $P 2_{1} / m$ setting $\left(P 2_{1} / m\right.$ is a sub-group of Pnma and is a direct translationgleiche type I subgroup relation) determined with the use of the program PowderCell 2.4 [29]. The $P 2_{1} / m$ structure could not be refined using the usual $P 2_{1} / m$ clinoamphibole structure (cummingtonite structure with ideal formula $\mathrm{Mg}_{2} \mathrm{Mg}_{5} \mathrm{Si}_{8} \mathrm{O}_{22}(\mathrm{OH})_{2}$ ), despite having the same space group. The unit cell volume and $\mathrm{Z}$ number in the high-pressure gedrite phase are twice the values for cummingtonite. Least-squares structure refinement for selected pressures was done with the program SHELXL2014 [17]. The procedure for refinement of the high-pressure structure was similar to the ambient pressure phase; however, all atoms in the high-pressure structure were refined with isotropic atomic displacement parameters (ADPs) due to limited coverage of the reciprocal space. The site occupancies in all the high-pressure refinements were constrained to those determined from the ambient structure refinement. Polyhedral geometry parameters were calculated using the program VESTA [30]. Details of the crystal structure refinement, refined fractional coordinates for all the atoms, bond lengths and atomic displacement parameters for selected pressures are given in Table 2, Table 3, and Table 4 and Supplementary Tables S2 and S3.

Table 1. Results from microprobe analyses.

\begin{tabular}{|c|c|c|c|c|c|c|c|}
\hline Constituent & Wt. $\%$ & Range & Stand. dev. & Probe Standard * & Crystal & Line & Cations/Formula \\
\hline $\mathrm{FeO}$ & 18.36 & $17.85-18.70$ & 0.29 & Garnet, Verma (Mn) & $\mathrm{LiF}$ & $\mathrm{K} \alpha$ & 2.245 \\
\hline $\mathrm{MgO}$ & 16.69 & $16.22-17.07$ & 0.23 & hromite USNM 117075 & TAP & $\mathrm{K} \alpha$ & \\
\hline $\mathrm{Na}_{2} \mathrm{O}$ & 1.52 & $1.45-1.66$ & 0.06 & Albite, Amelia & TAP & $\mathrm{K} \alpha$ & \\
\hline $\mathrm{Al}_{2} \mathrm{O}_{3}$ & 14.71 & $14.24-15.39$ & 0.37 & Chromite USNM 117075 & TAP & $\mathrm{K} \alpha$ & 2.535 \\
\hline $\mathrm{SiO}_{2}$ & 44.57 & $43.59-45.05$ & 0.43 & Albite, Amelia & TAP & $\mathrm{K} \alpha$ & 6.517 \\
\hline $\mathrm{CaO}$ & 0.14 & $0.12-0.16$ & 0.01 & Diopside-2 (UCLA) & PETH & $\mathrm{K} \alpha$ & 0.022 \\
\hline $\mathrm{MnO}$ & 0.03 & $0-0.07$ & 0.02 & Garnet, Verma (Mn) & $\mathrm{LiF}$ & $\mathrm{K} \alpha$ & 0.004 \\
\hline $\mathrm{Cl}$ & 0.00 & .02 & 0.01 & Scapolite & PETH & $\mathrm{K} \alpha$ & 0 \\
\hline $\mathrm{TiO}_{2}$ & 0.16 & $0.1-0.22$ & 0.03 & Sphene glass & $\mathrm{LiFH}$ & $\mathrm{K} \alpha$ & 0 \\
\hline $\mathrm{K}_{2} \mathrm{O}$ & 0.01 & $0-0.03$ & 0.01 & Orthoclase (OR-1) & РETH & $\mathrm{K} \alpha$ & 0.002 \\
\hline $\mathrm{Cr}_{2} \mathrm{O}_{3}$ & 0.02 & $0-0.07$ & 0.02 & Chromite USNM 117075 & $\mathrm{LiFH}$ & $\mathrm{K} \alpha$ & 0.003 \\
\hline Total & 96.21 & & & & & & \\
\hline \multicolumn{8}{|c|}{ 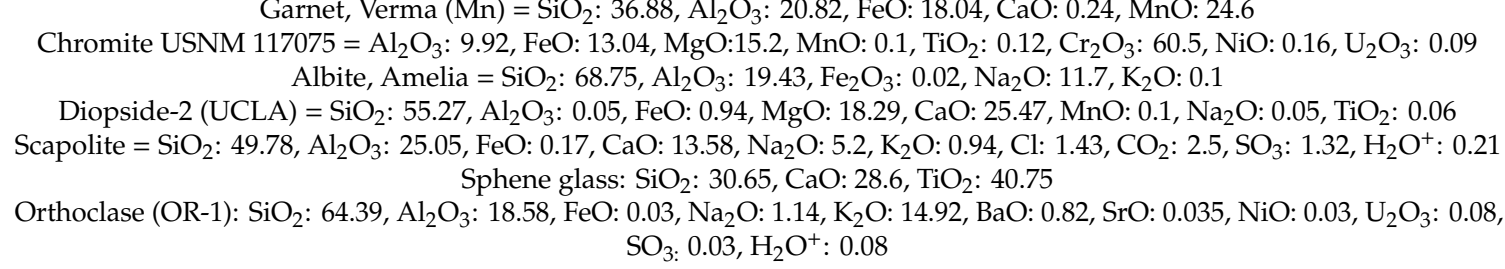 } \\
\hline
\end{tabular}

* Probe Standard Compositions (Wt.\%).

Table 2. Representative single-crystal structure refinement parameters for gedrite at selected pressures.

\begin{tabular}{cccc}
\hline Phase & Gedrite & Gedrite & $\beta$-gedrite \\
\hline Wavelength (̊̊) & 0.560 & 0.434 & 0.434 \\
Pressure (GPa) & Ambient & $10.6(5)$ & $21(1)$ \\
Temperature (K) & 298 & 298 & 298 \\
$\theta$ range for data collection & $2.502-30.733$ & $2.509-23.120$ & $2.472-23.133$ \\
No. of reflections collected & 20450 & 2898 & 3083 \\
No. of independent reflections & 5597 & 532 & 1073 \\
No. of restraints & 7 & 0 & 0 \\
No. of parameters refined & 206 & 87 & 173 \\
\hline & $-30 \leq h \leq 33$ & $-9 \leq h \leq 14$ & $-12 \leq h \leq 13$ \\
Limiting indices & $-32 \leq k \leq 26$ & $-18 \leq k \leq 21$ & $-21 \leq k \leq 17$ \\
& $-9 \leq l \leq 9$ & $-9 \leq l \leq 5$ & $-9 \leq l \leq 9$ \\
\hline Space Group & $P n m a$ & $P n m a$ & $P 2_{1} / m$ \\
\hline
\end{tabular}


Table 2. Cont.

\begin{tabular}{cccc}
\hline Phase & Gedrite & Gedrite & $\beta$-gedrite \\
\hline & $a=18.5385(5) \AA$ & $a=17.823(3) \AA$ & $a=17.514(3) \AA$ \\
Unit-cell dimensions & $b=17.8286(4) \AA$ & $b=17.427(1) \AA$ & $b=17.077(1) \AA, \beta=92.882^{\circ}$ \\
& $c=5.2780(1) \AA$ & $c=5.1598(1) \AA$ & $c=4.9907(2) \AA$ \\
\hline $\mathbf{R}_{\text {int }} \AA$ & 0.0395 & 0.0976 & 0.1126 \\
Refinement & $\mathrm{F}^{2}$ & $\mathrm{~F}^{2}$ & $\mathrm{~F}^{2}$ \\
Goodness-of-fit on $\mathbf{F}^{\mathbf{2}}$ & 1.228 & 0.1872 & 1.184 \\
wR $_{\mathbf{2}}$ [I >2sigma(I)] & 0.1293 & 0.0846 & 0.2026 \\
$\mathbf{R}_{\mathbf{1}}$ [I $\mathbf{\text { 2sigma(I)] }}$ & 0.0614 & & 0.0961 \\
\hline
\end{tabular}

Table 3. Unit cell parameters of gedrite at various pressures and $298 \mathrm{~K}$.

\begin{tabular}{|c|c|c|c|c|c|c|}
\hline Pressure (GPa) & $a(\AA)$ & $b(\AA)$ & $c(\AA)$ & $\beta\left(^{\circ}\right)$ & $V\left(\AA^{3}\right)$ & Space Group \\
\hline 0 & $18.5383(5)$ & $17.8286(4)$ & $5.2780(1)$ & 90 & $1744.44(1)$ & Pnma \\
\hline $1.84(9)$ & $18.416(4)$ & 17.754(1) & $5.2574(2)$ & 90 & $1718.9(4)$ & Pnma \\
\hline $4.3(2)$ & $18.223(5)$ & $17.651(1)$ & $5.2266(3)$ & 90 & $1681.2(5)$ & Pnma \\
\hline $10.6(5)$ & $17.823(3)$ & $17.427(1)$ & $5.1598(1)$ & 90 & $1602.6(3)$ & Pnma \\
\hline 15.1(7) & $17.591(8)$ & $17.301(2)$ & $5.1256(6)$ & 90 & $1560.0(7)$ & Pnma \\
\hline $21(1)$ & $17.514(3)$ & $17.077(1)$ & $4.9907(2)$ & $92.882(6)$ & $1490.82(5)$ & $P 2_{1} / m$ \\
\hline $27(1)$ & 17.247(9) & $16.908(3)$ & $4.0907(5)$ & $93.55(1)$ & $1429.06(8)$ & $P 2_{1} / m$ \\
\hline $24(1)$ & $17.355(4)$ & 16.975(1) & $4.9384(2)$ & $93.456(7)$ & $1452.3(3)$ & $P 2_{1} / m$ \\
\hline $22(1)$ & $17.418(5)$ & $17.016(2)$ & $4.9726(3)$ & $93.214(9)$ & $1471.5(5)$ & $P 2_{1} / m$ \\
\hline $20(1)$ & $17.456(4)$ & $17.039(1)$ & $4.9915(2)$ & $93.058(8)$ & $1482.5(4)$ & $P 2_{1} / m$ \\
\hline $15.8(8)$ & $17.605(9)$ & $17.215(3)$ & $5.0390(5)$ & $92.45(1)$ & $1525.8(8)$ & $P 2_{1} / m$ \\
\hline 14.2(7) & $17.585(6)$ & $17.298(2)$ & $5.1245(3)$ & 90 & $1558.9(5)$ & Pnma \\
\hline $6.1(3)$ & $18.01(1)$ & $17.570(7)$ & $5.199(1)$ & 90 & $1646(2)$ & Pnma \\
\hline $4.0(2)$ & $18.207(5)$ & $17.655(2)$ & $5.2291(3)$ & 90 & $1680.9(5)$ & Pnma \\
\hline
\end{tabular}

Table 4. Polyhedra volumes and distortion parameters of gedrite at various pressures and $298 \mathrm{~K}$.

\begin{tabular}{|c|c|c|c|c|}
\hline Polyhedra & $\begin{array}{l}\text { Average Bond } \\
\text { Length (Å) }\end{array}$ & $\begin{array}{c}\text { Polyhedral } \\
\text { Volume }\left(\AA^{3}\right)\end{array}$ & $\begin{array}{l}\text { Quadratic } \\
\text { Elongation }\end{array}$ & $\begin{array}{l}\text { Bond Angle } \\
\text { Variance }\left(\sigma^{2}\right)\end{array}$ \\
\hline \multicolumn{5}{|c|}{ Gedrite at ambient pressure, Pnma } \\
\hline M1 & 2.0934 & 11.93 & 1.0169 & 53.8375 \\
\hline M2 & 1.9941 & 10.47 & 1.0068 & 21.9492 \\
\hline M3 & 2.0829 & 11.62 & 1.0239 & 76.1937 \\
\hline M4 & 2.2025 & 13.01 & 1.0666 & 211.4892 \\
\hline \multicolumn{5}{|c|}{ Gedrite at 10.6(5) GPa, Pnma } \\
\hline M1 & 2.0527 & 11.34 & 1.0114 & 37.9025 \\
\hline M2 & 1.9510 & 9.82 & 1.0052 & 17.0948 \\
\hline M3 & 2.0417 & 11.10 & 1.0150 & 49.4618 \\
\hline M4 & 2.1360 & 11.88 & 1.0626 & 215.8653 \\
\hline \multicolumn{5}{|c|}{$\beta$-Gedrite at $21(1) \mathrm{GPa}, P 2_{1} / m$} \\
\hline M1 & 2.0236 & 10.91 & 1.0082 & 26.7785 \\
\hline $\mathrm{M} 1^{\prime}$ & 1.9844 & 10.28 & 1.0086 & 28.3585 \\
\hline M2 & 1.9207 & 9.39 & 1.0040 & 13.2891 \\
\hline $\mathrm{M} 2^{\prime}$ & 1.9211 & 9.39 & 1.0048 & 15.5441 \\
\hline M3 & 1.9992 & 10.44 & 1.0138 & 46.4812 \\
\hline $\mathrm{M}^{\prime}$ & 1.9764 & 10.10 & 1.0124 & 41.5350 \\
\hline M4 & 2.1090 & 12.09 & 1.0245 & 75.6850 \\
\hline $\mathrm{M} 4^{\prime}$ & 2.0552 & 10.95 & 1.0381 & 131.6104 \\
\hline
\end{tabular}




\section{Results}

At ambient temperature, the transformation of gedrite to $\beta$-gedrite takes place between 15.1(7) GPa and 21(1) GPa. This is the first known structural phase transformation reported for an orthorhombic amphibole group mineral. The indexing of the diffraction pattern at 21(1) GPa yielded a primitive monoclinic unit cell. The unit cell parameters are $a=17.514(3) \AA, b=17.077(1) \AA, c=4.9907(2) \AA$, and $\beta=92.882(5)^{\circ}$. Here, we report refinements for the orthorhombic gedrite structure at ambient pressure, 10.6(5) GPa and the high-pressure monoclinic phase at 21(1) GPa.

At ambient conditions, the unit cell parameters are $a=18.5383(5) \AA, b=17.8286(5) \AA$ and $c=5.2780(1) \AA$, which are consistent with Ref. [1], who reported $a=18.531(4) \AA, b=17.741(4) \AA$ and $c=5.249$ (5) $\AA$. At 21(1) GPa, we observed a new structure with monoclinic symmetry that we designate as $\beta$-gedrite, as evidenced by the appearance of new diffraction peaks, and confirmed by structure solution and refinement.

$\beta$-gedrite has $P 2_{1} / m$ symmetry, which is the same space group as the low-pressure $P 2_{1} / m$ clinoamphiboles, such as cummingtonite. However, it corresponds to a distinctly different structural arrangement, with a double number of formula units per unit cell. Upon decompression to 14.2(7) GPa, the Pnma orthorhombic structure reappeared, as indicated by a change in systematic absences. Thus, the transition is entirely reversible. We refined this new structure at 21(1) GPa to an R1 value of $9.6 \%$. The higher R1 value, compared to the orthorhombic structure, is due to a combination of limited coverage in reciprocal space and broadening of diffraction peaks with a larger rocking curve.

In $\beta$-gedrite the reduction in symmetry causes a splitting of the atomic sites in comparison to the orthorhombic structure. The M1, M2 and M4 sites are located on Wyckoff positions 8d in the orthorhombic structure and split into two different sites in the monoclinic structure which occupy Wyckoff positions 4f. Similarly, the A, M3, O3A, O3B, O7A and O7B sites, which occupy Wyckoff position $4 \mathrm{c}$ in the orthorhombic structure, split to occupy Wyckoff position 2e. All remaining oxygen atoms are located on general position $8 \mathrm{~d}$, which split into two Wyckoff positions $4 \mathrm{f}$. As a consequence of the splitting of the Wyckoff positions, there is a doubling in the number of sites in the $\beta$-gedrite structure compared to the orthorhombic phase. We define the new sites resulting from the Wyckoff positions splitting with a prime symbol (e.g., M4 site in the gedrite structure splitting to become M4 and M4' in the $\beta$-gedrite structure).

A comparison of the crystal structures of gedrite and $\beta$-gedrite is shown in Figures 1 and 2. $\beta$-gedrite is a novel amphibole structure, showing the existence of four non-equivalent tetrahedral chains. The transformation observed in gedrite from Pnma to $P 2_{1} / m$ symmetry is analogous to the $\alpha-\beta$ orthopyroxene high-pressure transformation, where the number of crystallographically distinct silicate chains doubles from two to four $[11,12]$. We define the new silicate chains that result from the Wyckoff position splitting as $\mathrm{A}^{\prime}$ and $\mathrm{B}^{\prime}$. Using the bulk modulus and bulk modulus derivative determined from the third-order Birch-Murnaghan equation of state [15], we extrapolate the hypothetical unit-cell volume of our crystal to be $1548.16 \AA^{3}$ at $15.8 \mathrm{GPa}$ in the gedrite phase. At the same pressure, the unit cell volume of $\beta$-gedrite is 1525.8(8) $\AA^{3}$ (Table 3). The volume discontinuity accompanying the $\alpha-\beta$ gedrite phase transition is $1.4 \%$, compared with a $1.2 \%$ volume discontinuity in the $\alpha-\beta$ opx phase transition [12]. Based on the unit cell volume discontinuity, we classify the $\alpha$ - $\beta$ gedrite phase transition as first order.

The O5-O6-O5 angle characterizes kinking of the double-silicate chains. At ambient conditions, the kinking angles of the A chain and B chain in gedrite are $163.8(1)^{\circ}$ and $148.0(1)^{\circ}$, respectively. With pressure increasing to $10.6(5) \mathrm{GPa}$, the double-silicate chains become more kinked (chain shortening), and the angles decrease to $158(1)^{\circ}$ and $140.1(9)^{\circ}$ for the A chain and B chain. In the new $\beta$-gedrite phase at 21(1) GPa, each of the four silicate double-chains displays extreme kinking with angles of $138.2(9)^{\circ}, 142.7(8), 134.6(8)^{\circ}$ and $134.5(8)^{\circ}$ for the $\mathrm{A}, \mathrm{A}^{\prime}, \mathrm{B}, \mathrm{B}^{\prime}$ chain, respectively. During compression in the orthorhombic phase, the sense of rotation for the $\mathrm{A}$ and $\mathrm{B}$ chain remains O-type. In O-type rotations, the triangular faces (approximately normal to $a^{*}$ ) of the tetrahedra in the double-silicate chains rotate so that they are directed opposite to the triangular faces of the octahedra 
to which they are linked. In S-type rotations, the triangular faces of the tetrahedra and the octahedra are similarly directed (see [1] for a review on S- and O-type rotations). As the double-silicate chains split into four crystallographically distinct chains, we observe a change in the sense of rotation for the A chain as it becomes S-rotated (Figure 1). The remaining three chains remain O-rotated in the new monoclinic phase. The change in the sense of rotation for the A chain is comparable to the $\alpha-\beta$ opx transition [11,12]. In the $\alpha-\beta$ opx transition, the SiA and SiB chain, which are both in an O-type configuration in the $\alpha$-phase, split into four non-equivalent single-chains defined as $\mathrm{SiA}, \mathrm{SiB}, \mathrm{SiC}$ and $\mathrm{SiD}$ in the $\beta$-phase. The $\mathrm{SiB}$ chain coverts to an S-type of rotation, while the $\mathrm{SiA}, \mathrm{SiC}$, and $\mathrm{SiD}$ chains remain O-type, which is analogous to the pressure-induced phase transformation behavior of orthoamphibole observed in this study. Despite the change in rotation type for the A chain in $\beta$-gedrite, the stacking sequence of the I-beams remains the same as in the orthorhombic phase, and can still be described as $(+,+,-,-)$, which is different from the stacking sequence of $\mathrm{P} 2{ }_{1} / \mathrm{m}$ clinoamphiboles $(+,+$, $+,+)$. Positively $(+)$-directed strips are defined as those in which the lower-triangular faces of a given octahedral strip (viewed along $a^{*}$ ) have one of their three apices pointing in the $+c$ direction. If these lower faces have one of their apices pointing in the $-c$ direction, it is negatively directed [1]. This, again, is analogous to the mechanism of the phase transition behavior observed by Ref. [11] in orthoenstatite where the stacking sequence of the ambient phase is preserved in the high-pressure phase. Figure 2 illustrates the I-beam stacking in gedrite, $\beta$-gedrite and low-pressure $P 2_{1} / m$ clinoamphiboles.
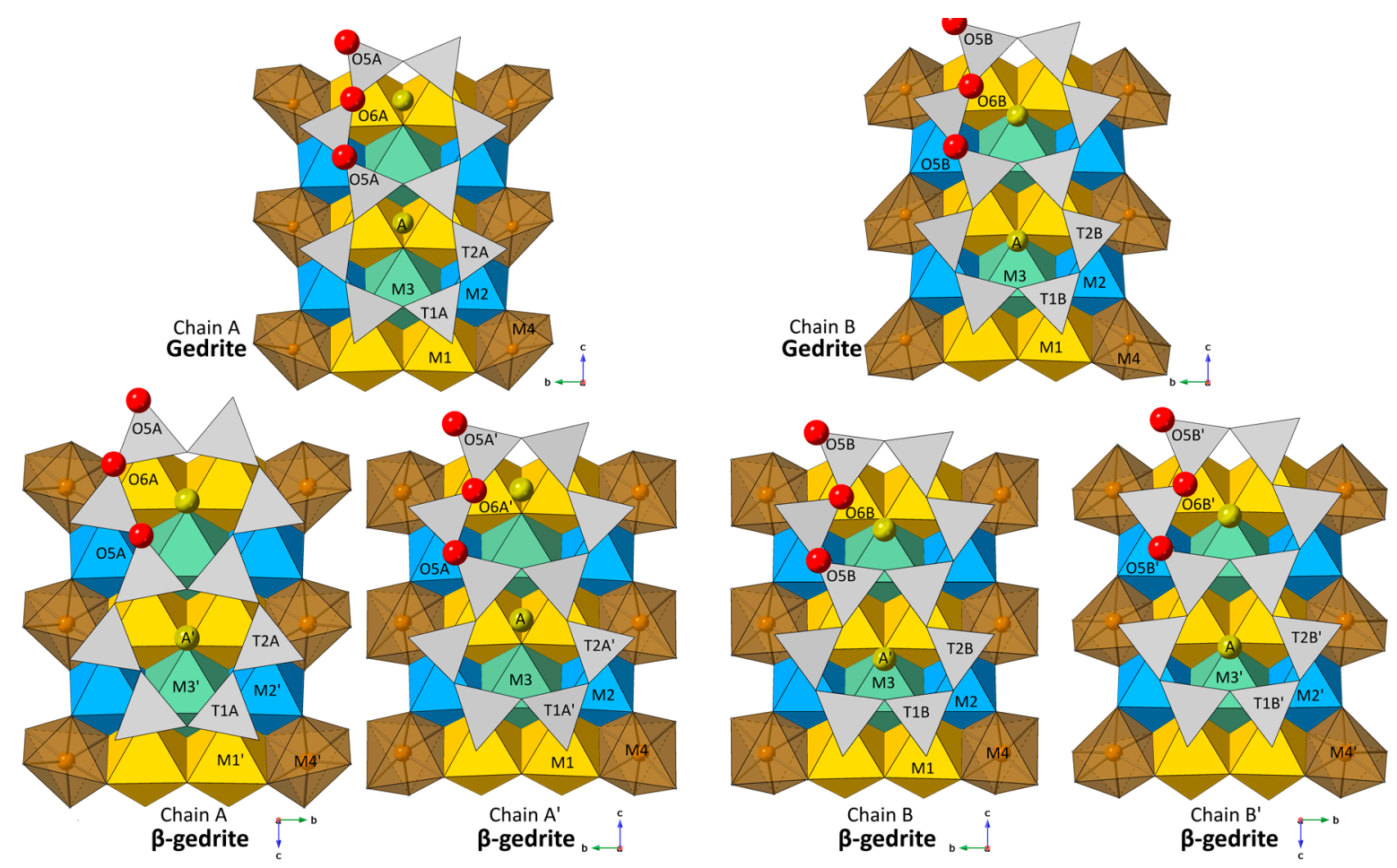

Figure 1. (100) projection of the partial structure of gedrite showing the structural changes from gedrite (Pnma) to $\beta$-gedrite $\left(\mathrm{P}_{1} / \mathrm{m}\right)$. The reduction in symmetry splits the double-chains of tetrahedra into four nonequivalent chains in the $P 2_{1} / m$ phase. The $A$ chain in the $\beta$-gedrite structure has S-type rotation while the $\mathrm{A}^{\prime}$, B and $\mathrm{B}^{\prime}$ chains are O-rotated. Oxygen atoms are shown as red spheres. O5-O6-O5 angles are measured as the obtuse angle. 


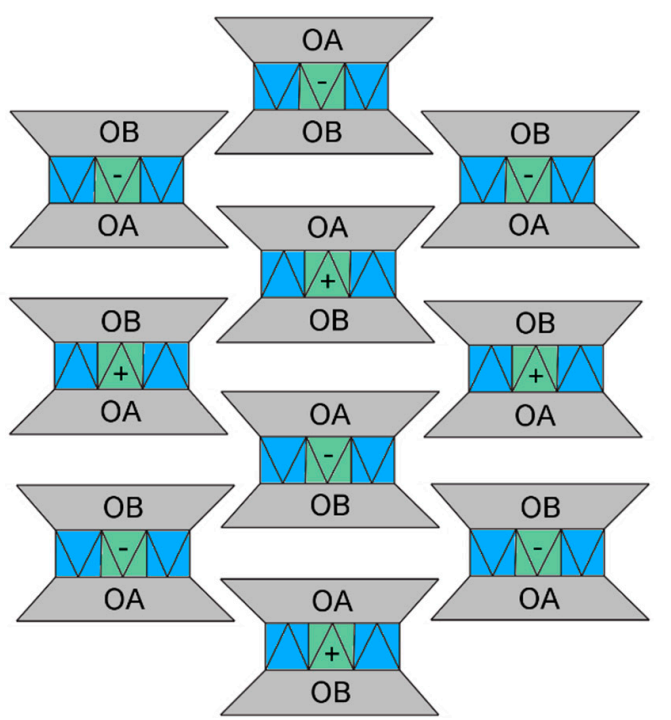

Gedrite

Pnma

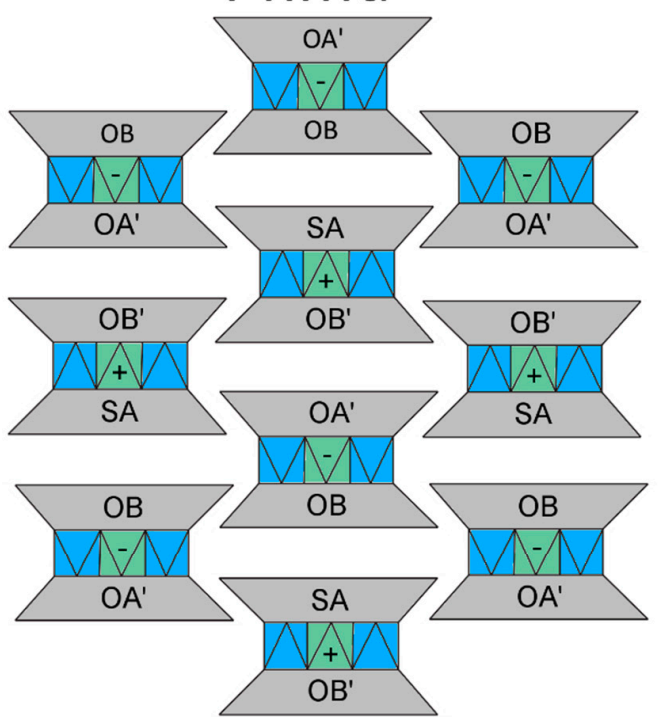

$\beta$-gedrite $P 2_{1} / m$

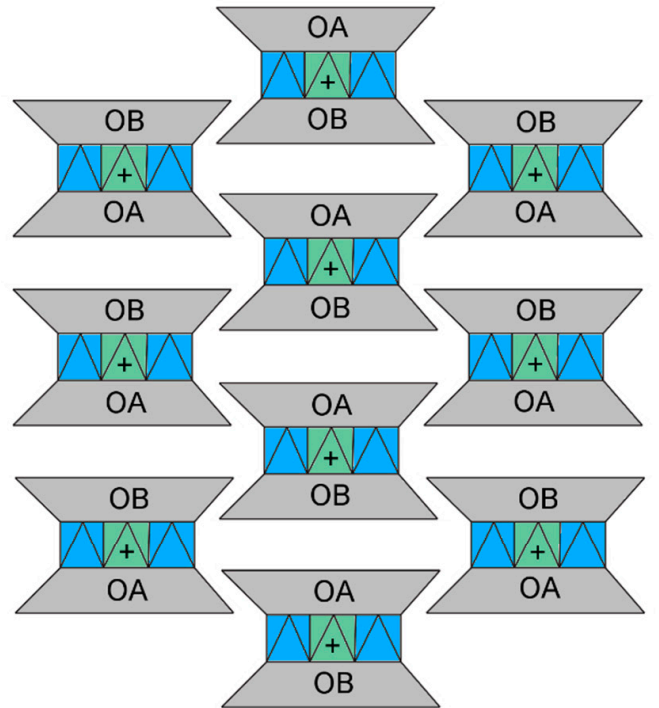

Clinoamphibole $P 21 / m$

Figure 2. I-beam topological representation of gedrite, $\beta$-gedrite and $P 2_{1} / m$ clinoamphibole. The I-beam stacking sequence in $\beta$-gedrite remains the same as the ambient phase $(+,+,-,-)$ despite the change in rotation type for the A-chain. The $\beta$-gedrite and $P 2_{1} / m$ clinoamphiboles are different structures, as evidenced by their different stacking sequence.

At ambient pressure, the polyhedral volumes of the M1, M2, M3, and M4 sites are 11.93, 10.47, 11.62, $13.01 \AA^{3}$, respectively (Table 4). Measures of polyhedral geometry distortion, quadratic elongation and bond angle variances at ambient pressures are 1.0169 and 53.79 for M1, 1.0068 and 21.97 for M2, 1.0239 and 76.03 for M3, and 1.0666 and 211.47 for M4. At 10.6(5) GPa, the polyhedra volumes for the M1, M2, M3, and M4 sites are 11.34, 9.82, 11.10, $11.88 \AA^{3}$, respectively. Octahedral geometry parameters for M1, M2, M3, and M4 are 1.0114, 1.0052, 1.0150 and 1.0626 for quadratic elongation and 37.90, $17.09,49.46$ and 215.86 for bond angle variance. With increasing pressure, the M1, M2, and M3 polyhedra 
become more regular, as evidenced by the angle variance and quadratic elongation [31], while the M4 polyhedron becomes slightly more distorted.

In the new $\beta$-gedrite phase at 21(1) GPa, polyhedral geometry parameters of the octahedral sites $\mathrm{M}$ and $\mathrm{M}^{\prime}$ are in close agreement with each other except for M4 and $\mathrm{M}^{\prime}$ (Table 4). The polyhedral volume for M4 and M4' are 12.09 and $10.95 \AA^{3}$, respectively. M4 and M4' have values of 1.0245 and 1.0381 for quadratic elongation, and 75.68 and 131.61 for bond angle variance. M4 and M4' polyhedra are more regular in the $\beta$-gedrite phase, as compared to the ambient gedrite phase, as evidenced by their quadratic elongation and bond angle variance values. By similar reasoning, in the $\beta$-gedrite phase, the M4' polyhedron is more distorted than the M4 polyhedron.

The extreme kinking of the double-silicate chains, especially in the A-chain, which splits to the A (S-rotated) and $\mathrm{A}^{\prime}(\mathrm{O}$-rotated) chain in $\beta$-gedrite (Figure 1$)$, modifies the coordination environment of the $\mathrm{M} 4$ site. In the ambient phase, the $\mathrm{M} 4$ central ion is bonded to $\mathrm{O} 2 \mathrm{~A}, \mathrm{O} 2 \mathrm{~B}, \mathrm{O} 4 \mathrm{~A}, \mathrm{O} 4 \mathrm{~B}, \mathrm{O} 5 \mathrm{~A}$, and $\mathrm{O} 5 \mathrm{~B}$ and the polyhedron shares an edge with the T2A tetrahedra. In the new phase, M4 bonds to $\mathrm{O} 2 \mathrm{~A}$, $\mathrm{O} 2 \mathrm{~B}, \mathrm{O} 4 \mathrm{~A}, \mathrm{O} 4 \mathrm{~B}, \mathrm{O} 5 \mathrm{~B}$ and $\mathrm{O} 6 \mathrm{~A}$, and $\mathrm{M}^{\prime}$ bonds to $\mathrm{O}_{2} \mathrm{~A}^{\prime}, \mathrm{O}^{2} \mathrm{~B}^{\prime}, \mathrm{O}^{\prime} \mathrm{A}^{\prime}, \mathrm{O}^{\prime} \mathrm{B}^{\prime}, \mathrm{O}^{\prime} \mathrm{A}^{\prime}$, and $\mathrm{O}^{\mathrm{B}} \mathrm{B}^{\prime}$ (Figure 3). Due to the shift in the coordination environment of the M4 site, the M4 polyhedron no longer shares any edges with surrounding silicate tetrahedra, while the $\mathrm{M}^{\prime}$ polyhedron shares one edge with the T2A' tetrahedra (Figure 4). The absence of edge sharing in the M4 polyhedron leads to an increase in stability due to a decrease in cation-cation repulsion, which is energetically favorable, according to Pauling's rule. The shared edge of the M4' polyhedron causes it to become more distorted than the M4 polyhedron, which is validated by the polyhedral geometry parameters.
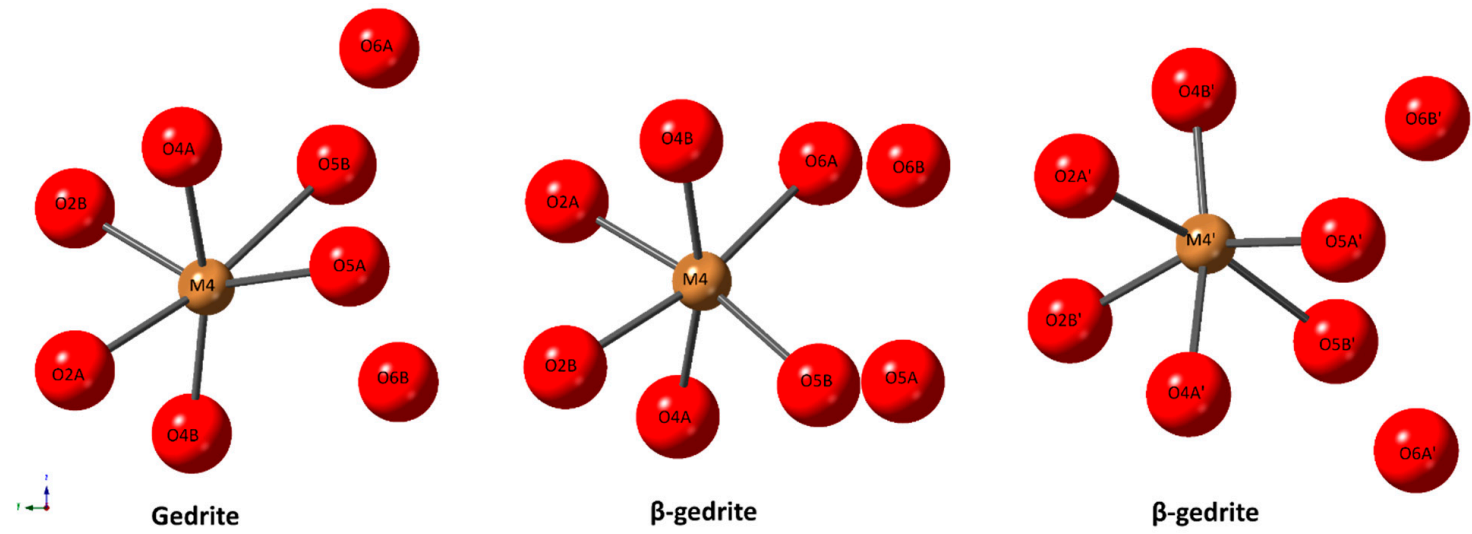

Figure 3. Atomic coordination of the M4 cation in gedrite and $\beta$-gedrite.

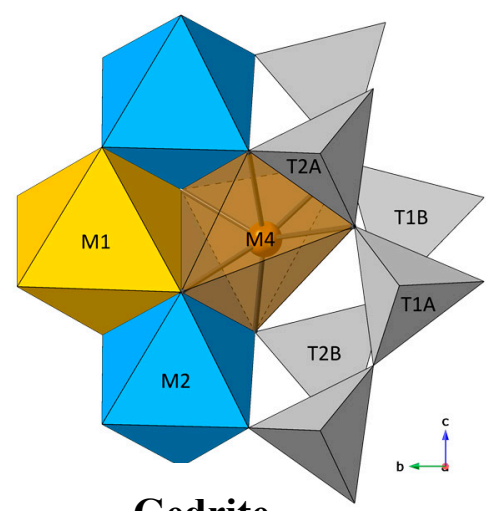

Gedrite

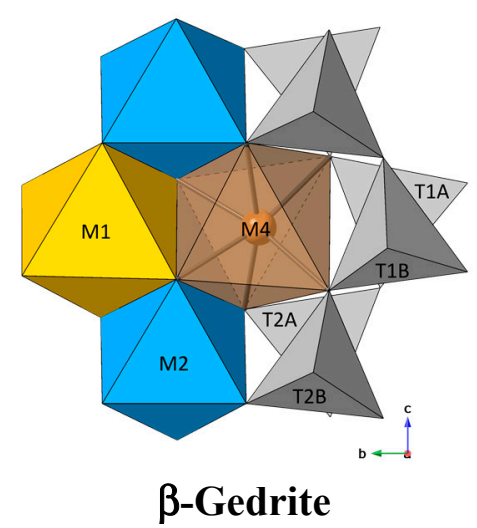

$\beta$-Gedrite

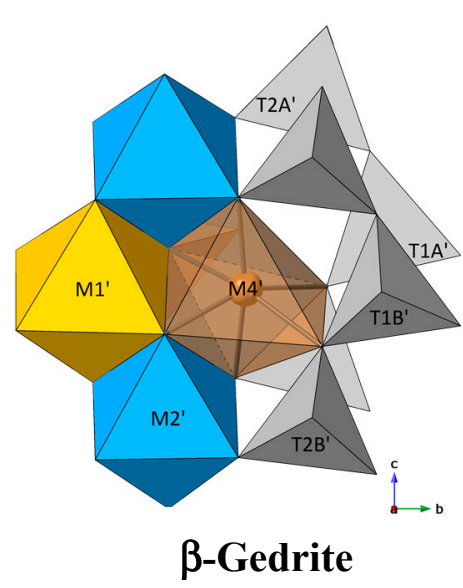

$\beta$-Gedrite

Figure 4. M4 polyhedral configuration in gedrite. The M4 polyhedron in $\beta$-gedrite is no longer sharing any edges with adjacent tetrahedra from the double-chains. 


\section{Discussion}

Equilibrium-phase transformation sequences of the major rock-forming minerals along an average mantle geotherm have been extensively studied. However, metastable behavior under disequilibrium conditions is poorly understood. Metastability may arise from the kinetic hindrance of reactions, due to low temperatures within slabs. The metastable persistence of low-pressure phases into the stability fields of high-pressure phases and spatial variations in mineralogy may contribute to petrological buoyancy forces and have significant geophysical implications. Seismological studies indicate that subduction zones display significant variations in their geometry, with some slabs maintaining an approximately constant dip angle, while others show lateral deflection at the top of the lower mantle, indicating stagnation $[32,33]$. The metastability of olivine and pyroxene might be a reason for the slab stagnation within the transition zone due to low-density metastable phases, which provide positive buoyancy effects [34-36].

Several studies have been devoted to determining the stability fields of various amphiboles. Ref. [37] investigated the stability of gedrite with a series of reactions up to $0.2 \mathrm{GPa}$ and found that the breakdown temperature of gedrite increased with higher pressures. Ref. [7] observed dehydrogenation in gedrite at $973 \mathrm{~K}$ and ambient pressure with the onset of new behavior in the B-chain at $723 \mathrm{~K}$. K-amphibole was found to be stable at pressures up to $16 \mathrm{GPa}$ and below $1200{ }^{\circ} \mathrm{C}$ [38]. Additional experiments on potassic richterite $\left(\mathrm{KNaCaMg}_{5} \mathrm{Si}_{8} \mathrm{O}_{22}(\mathrm{OH})_{2}\right)$ by Ref. [39] have shown that $\mathrm{K}$-richterite is stable to about $1450{ }^{\circ} \mathrm{C}$ at $9-10 \mathrm{GPa}$. At higher pressures, the Clapeyron slope of amphibole breakdown changes sign, suggesting a lower breakdown temperature at even higher pressures. However, at $1000^{\circ} \mathrm{C}$, potassic richterite was still stable up to $14 \mathrm{GPa}$. More recently, Ref. [40] demonstrated that pargasite, $\mathrm{NaCa}_{2}\left(\mathrm{Mg}_{4} \mathrm{Al}\right)\left(\mathrm{Si}_{6} \mathrm{Al}_{2}\right) \mathrm{O}_{22}(\mathrm{OH})_{2}$, is stable up to at least $16.5 \mathrm{GPa}$ and $\sim 1200 \mathrm{~K}$ without any evidence of de-hydroxylation. In attempting to quantify the effects of the bulk composition of amphiboles, Ref. [41] determined that a high alkali content stabilizes amphiboles to higher pressures and temperatures; high bulk $\mathrm{Na} / \mathrm{Ca}$ ratios $\left(\mathrm{Na}_{2} \mathrm{O} / \mathrm{CaO}>\sim 0.5\right)$ stabilize a highly sodic amphibole to higher pressures at the expense of clinopyroxene; high bulk $\mathrm{Na} / \mathrm{Ca}$ ratios have lower temperature stability limits, and $\mathrm{Ti}$ (and possibly $\mathrm{Cr}$ ) stabilizes amphiboles. It can be asserted from these observations that the stability of amphiboles is highly dependent on their bulk composition. From these previous studies, it has been demonstrated that it is possible for the stability fields of certain amphibole species to extend up to $\sim 16 \mathrm{GPa}$ and $\sim 1450{ }^{\circ} \mathrm{C}$. Based on the upper limits of these stability fields and the ambient pressure thermal decomposition temperature of gedrite $(973 \mathrm{~K})$, metastable persistence into higher pressure $(\sim 20 \mathrm{GPa})$ but lower temperature domains $\left(<700^{\circ} \mathrm{C}\right)$ are possible.

In estimating the total volume fraction of amphiboles present within a downgoing slab, studies have not considered transport pathways under disequilibrium conditions. It has been estimated that amphiboles can form up to $20 \%-60 \%$ of basalts to around $2.4 \mathrm{GPa}$ and roughly $600{ }^{\circ} \mathrm{C}$ or up to $30 \%-50 \%$ by volume in metabasalt between 1-3 GPa and over a temperature range of $850-1000{ }^{\circ} \mathrm{C}[42,43]$. Subducted slabs vary significantly in terms of the rate of subduction, depending on the age of the subducted lithosphere [36]. It is possible that a large volume fraction of amphibole remains present within portions of a subducting slab, if the slab is very cold, below the amphibole breakdown temperature. Furthermore, it is conceivable that metastable amphiboles like $\beta$-gedrite are preserved to greater depths in the cold slabs. Some geophysical and petrological models have assumed that subduction can extend to depths greater than $660 \mathrm{~km}$, while remaining below $700{ }^{\circ} \mathrm{C}$ [32,44-46], suggesting that it is plausible that amphiboles could be metastably transported along disequilibrium pathways to experience pressures higher than $20 \mathrm{GPa}$, while still at temperatures lower than expected for amphibole dissolution or dehydration. As amphiboles react to form denser phases such as clinopyroxenes, orthopyroxenes, olivines, spinels and garnets, metastable preservation of amphiboles would deliver a positive buoyancy effect to the subducting slab. Depending on the volume fraction of metastable amphibole present within the slab, it could potentially contribute to slab stagnation.

The metastable preservation of amphiboles to greater depths has further implications, as they are a source of water for partial melting and devolatilization in subducting slabs. Dehydration reactions in 
subducting slabs generally liberate water as a fluid phase, which has implications in magmatic and intermediate-depth seismic processes [34]. Ref. [47] observed that dehydration of serpentinite causes weakening, as well as changing the failure mode from ductile yielding to shear fracturing. Ref. [48] suggested that water vapor released from dehydration of hydrous minerals, such as amphiboles, would reduce friction and make brittle fractures possible at greater depths, a process known as dehydration embrittlement. Dehydration embrittlement has been proposed to be an essential mechanism for faulting processes for intermediate and possibly deep earthquakes [42,47,49-54]. With the metastable preservation of amphiboles, dehydration reactions would be expected to occur at higher pressures than previously assumed, and may lead to dehydration embrittlement at greater depths.

The $\mathrm{H}_{2} \mathrm{O}$ content in amphiboles is moderate, at $1.5-4 \mathrm{wt} \%$, compared with serpentine minerals, which can accommodate up to $13 \mathrm{wt} \%$ of $\mathrm{H}_{2} \mathrm{O}$ [55-57]. It was previously assumed that dehydration embrittlement enabled shear failure due to the production of pore pressure as a consequence of a positive volume change of dehydration reactions and consequent decrease in the effective pressure on existing planes of weakness. However, deformation experiments on antigorite serpentinite [53], indicate that the initiation of earthquakes through dehydration embrittlement is not restricted to a positive volume change, but rather involves separation of fluid from solid reaction products. Alternatively, Ref. [58] hypothesized the existence of an earthquake sliding mechanism that is controlled by phase transformations and demonstrated that nanocrystalline aggregates of solid reaction products promote grain boundary sliding even in the absence of fluid. Deformation experiments on amphibolite (containing 53\% amphibole) have similarly been found to produce several microstructures at the sub-micrometer and nanometer scale [59]. Deformed natural rock samples produced microfaulting as discrete cracks or broad bands of very high dislocation density with local glassy patches and sub-micron-scale crystal fragments. Deformed synthetic amphibolite (hot pressed powder of the natural sample) contained several microstructural features probably related to the chemical breakdown of amphibole: $20 \mathrm{~nm}$ diameter tubes, pores, and small subhedral neoblasts of pyroxene. Another important observation, using bright-field TEM, is the presence of nanoscale amorphous material in rocks that underwent hydration during eclogite-blueschist transformation in an ancient subduction zone [60]. The amorphous material filled a pore between reacting $\mathrm{NaCa}$-amphibole and crystallizing Na-amphibole. These observations from Refs. $[59,60]$ suggest that the dehydration of amphibole is likely to produce nanometric solid products, which may allow for seismogenesis upon dehydration due to the promotion of grain boundary sliding. Furthermore, ref. [61] demonstrated that little dehydration is required to trigger embrittlement through deformation experiments on serpentinized peridotites and proposed that dehydration-driven stress transfer is what causes embrittlement. Consequently, it is likely that dehydration of amphiboles could lead to dehydration embrittlement, even up to $20 \mathrm{GPa}$, despite the modest $\mathrm{H}_{2} \mathrm{O}$ content compared to serpentine minerals. In any case, the complex interplay between metastable preservation, dehydration embrittlement and phase transformation behavior illustrate the potential for metastable amphiboles to be a possible trigger for seismic events.

\section{Conclusions}

Our study has shown the existence of a new phase of gedrite above 21(1) GPa. This study is the first structural report to show the existence of a phase transition in an orthorhombic amphibole. The gedrite to $\beta$-gedrite phase transition is characterized by lowering of crystal symmetry to one featuring four crystallographically distinct double-silicate chains with smaller kinking angles, the change in rotation type from O-type to S-type in one of the double-chains and the shift in M4 site coordination to share one edge less with surrounding silicate tetrahedra. Ref. [10] concluded that the high-temperature to low-temperature displacive transformations in amphiboles and pyroxenes are exactly analogous, even in the resulting microstructures. The existence of $\beta$-gedrite illustrates that this relationship is not limited to temperature-induced polymorphism, but also extends to compression-driven phase changes, due to the structural similarities and comparable volume discontinuities. Recent experiments on a clinoamphibole, grunerite, have shown the parallel structural relations and phase transformation behavior of both 
monoclinic single- and double-chain silicates [62], and our study extends this observation to also include orthorhombic inosilicates. As the gedrite to $\beta$-gedrite phase transition closely parallels those seen in orthopyroxenes [11,12], it is conceivable that a higher-pressure phase transition back to orthorhombic symmetry exists at higher pressures. Further investigations following disequilibrium pathways that deviate from a mantle adiabat are needed to constrain the thermodynamics and kinetics of metastable transformations, such as the one seen in this study, as they may have significant implications for petrological and geophysical processes.

Supplementary Materials: The following are available online at http://www.mdpi.com/2073-4352/9/10/521/s1, Table S1. Hydrogen-bond and intermolecular contact interaction geometry; Table S2. Refined fractional atomic coordinates and isotropic displacement parameters for gedrite at selected pressures; Table S3. Anisotropic displacement parameters for gedrite at ambient pressure.

Author Contributions: Conceptualization, T.Y., P.D. and G.J.F; methodology, D.Z. and P.D.; software, P.D.; validation, C.R.B.; formal analysis, T.Y., P.D. and G.J.F; investigation, T.Y. and P.D.; writing-original draft preparation, T.Y.; writing-review and editing, T.Y., P.D., C.R.B. and G.J.F; visualization, T.Y.; supervision, P.D.; project administration, P.D.; funding acquisition, P.D.

Funding: The project was supported by the National Science Foundation grant EAR 1722969. Portions of the X-ray diffraction work were conducted using the X-ray Atlas instrument at the University of Hawaii, funded by NSF grant EAR 1541516. Portions of this work were performed at GeoSoilEnviroCARS (Sector 13), Advanced Photon Source (APS), and Argonne National Laboratory. PX^2 program and the COMPRES-GSECARS gas loading system are supported by COMPRES under NSF Cooperative Agreement EAR-1661511. GeoSoilEnviroCARS is supported by the National Science Foundation-Earth Sciences (EAR-1128799) and Department of Energy-Geosciences (DE-FG02-94ER14466). Use of the Advanced Photon Source was supported by the US Department of Energy, Office of Science, Office of Basic Energy Sciences, under Contract No. DE-AC02-06CH11357.

Conflicts of Interest: The authors declare no conflict of interest.

\section{References}

1. Papike, J.; Ross, M. Gedrites: Crystal structures and intracrystalline cation distributions. Am. Mineral. 1970, 55, 1945-1972.

2. Papike, J.J.; Cameron, M. Crystal chemistry of silicate minerals of geophysical interest. Rev. Geophys. 1976, 14,37-80. [CrossRef]

3. Law, A.D.; Whittaker, E.J.W. Rotated and extended model structures in amphiboles and pyroxenes. Mineral. Mag. 1980, 43, 565-574. [CrossRef]

4. Hawthorne, F.C.; Oberti, R. Amphiboles: Crystal chemistry. Rev. Mineral. Geochem. 2007, 67, 1-54. [CrossRef]

5. Tuisku, P. Contact zone interaction of metabasites with metapelites: Amphibolite facies mineral assemblages, chemical profiles and their origin, the Puolankajärvi Formation, Finland. Lithos 1991, 27, 279-300. [CrossRef]

6. Schumacher, J.C.; Robinson, P. Mineral chemistry and metasomatic growth of aluminous enclaves in gedrite-cordierite-gneiss from southwestern new hampshire, USA. J. Petrol. 1987, 28, 1033-1073. [CrossRef]

7. Zema, M.; Welch, M.D.; Oberti, R. High-T behaviour of gedrite: Thermoelasticity, cation ordering and dehydrogenation. Contrib. Mineral. Petrol. 2012, 163, 923-937. [CrossRef]

8. Warren, B., II. The structure of tremolite $\mathrm{H}_{2} \mathrm{Ca}_{2} \mathrm{Mg}_{5}\left(\mathrm{SiO}_{3}\right)_{8}$. Z. Krist.-Cryst. Mater. 1930, 72, 42-57. [CrossRef]

9. Warren, B.; Modell, D. 11. The structure of anthophyllite $\mathrm{H}_{2} \mathrm{Mg}_{7}\left(\mathrm{SiO}_{3}\right)_{8}$. Z. Krist.-Cryst. Mater. 1930, 75, 161-178. [CrossRef]

10. Carpenter, M. Amphibole microstructures: Some analogies with phase transformations in pyroxenes. Mineral. Mag. 1982, 46, 395-397. [CrossRef]

11. Zhang, J.S.; Dera, P.; Bass, J.D. A new high-pressure phase transition in natural Fe-bearing orthoenstatite. Am. Mineral. 2012, 97, 1070-1074. [CrossRef]

12. Dera, P.; Finkelstein, G.J.; Duffy, T.S.; Downs, R.T.; Meng, Y.; Prakapenka, V.; Tkachev, S. Metastable high-pressure transformations of orthoferrosilite $\mathrm{Fs}_{82}$. Phys. Earth Planet. Inter. 2013, 221, 15-21. [CrossRef]

13. Finkelstein, G.J.; Dera, P.K.; Duffy, T.S. Phase transitions in orthopyroxene (En 90) to 49GPa from single-crystal X-ray diffraction. Phys. Earth Planet. Inter. 2015, 244, 78-86. [CrossRef] 
14. Welch, M.D.; Gatta, D.; Rotiroti, N. The high-pressure behavior of orthorhombic amphiboles. Am. Mineral. 2011, 96, 623. [CrossRef]

15. Nestola, F.; Pasqual, D.; Welch, M.D.; Oberti, R. The effects of composition upon the high-pressure behaviour of amphiboles: Compression of gedrite to $7 \mathrm{GPa}$ and a comparison with anthophyllite and proto-amphibole. Mineral. Mag. 2012, 76, 987-995. [CrossRef]

16. Welch, M.D.; Caámara, F.; Della Ventura, G.; Iezzi, G. Non-Ambient in situ studies of amphiboles. Rev. Mineral. Geochem. 2007, 67, 223-260. [CrossRef]

17. Sheldrick, G.M. Crystal structure refinement with SHELXL. Acta Crystallogr. Sect. C: Struct. Chem. 2015, 71, 3-8. [CrossRef] [PubMed]

18. Oberti, R.; Hawthorne, F.C.; Cannillo, E.; Caámara, F. Long-range order in amphiboles. Rev. Mineral. Geochem. 2007, 67, 125-171. [CrossRef]

19. Schindler, M.; Sokolova, E.; Abdu, Y.; Hawthorne, F.C.; Evans, B.W.; Ishida, K. The crystal chemistry of the gedrite-group amphiboles. I. Crystal structure and site populations. Mineral. Mag. 2008, 72, 703-730. [CrossRef]

20. Zhang, D.; Dera, P.K.; Eng, P.J.; Stubbs, J.E.; Zhang, J.S.; Prakapenka, V.B.; Rivers, M.L. High pressure single crystal diffraction at PX^2. J. Vis. Exp. 2017, 199, 54660. [CrossRef]

21. Boehler, R.; de Hantsetters, K. New anvil designs in diamond-cells. High Press. Res. 2004, 24, 391-396. [CrossRef]

22. Dewaele, A.; Torrent, M.; Loubeyre, P.; Mezouar, M. Compression curves of transition metals in the Mbar range: Experiments and projector augmented-wave calculations. Phys. Rev. B 2008, 78, 104102. [CrossRef]

23. Rivers, M.; Prakapenka, V.B.; Kubo, A.; Pullins, C.; Holl, C.M.; Jacobsen, S.D. The COMPRES/GSECARS gas-loading system for diamond anvil cells at the advanced photon source. High Press. Res. 2008, 28, 273-292. [CrossRef]

24. Finger, L.; Hazen, R.M.; Zou, G.; Mao, H.; Bell, P.M. Structure and compression of crystalline argon and neon at high pressure and room temperature. Appl. Phys. Lett. 1981, 39, 892-894. [CrossRef]

25. Jephcoat, A.P.; Mao, H.; Bell, P.M. Static compression of iron to $78 \mathrm{GPa}$ with rare gas solids as pressure-transmitting media. J. Geophys. Res.: Solid Earth 1986, 91, 4677-4684. [CrossRef]

26. Zha, C.-S.; Mao, H.; Hemley, R.J. Elasticity of $\mathrm{MgO}$ and a primary pressure scale to 55 GPa. Proc. Natl. Acad. Sci. USA 2000, 97, 13494-13499.

27. Dera, P. GSE-ADA Data Analysis Program for Monochromatic Single Crystal Diffraction with Area Detector; GeoSoilEnviroCARS: Argonne, IL, USA, 2007.

28. Dera, P.; Zhuravlev, K.; Prakapenka, V.; Rivers, M.L.; Finkelstein, G.J.; Grubor-Urosevic, O. High pressure single-crystal micro X-ray diffraction analysis with GSE_ADA/RSV software. High Press. Res. 2013, 33, 466-484. [CrossRef]

29. Kraus, W.; Nolze, G. Powder cell: A program for the representation and manipulation of crystal structure and calculation of the resulting x-ray powder pattern. J. Appl. Cryst. 1996, 29, 301-303. [CrossRef]

30. Momma, K.; Izumi, F. VESTA 3 for three-dimensional visualization of crystal, volumetric and morphology data. J. Appl. Cryst. 2011, 44, 1272-1276. [CrossRef]

31. Robinson, K.; Gibbs, G.; Ribbe, P. Quadratic elongation: A quantitative measure of distortion in coordination polyhedra. Science 1971, 172, 567-570. [CrossRef]

32. Bina, C.R.; Stein, S.; Marton, F.C.; Van Ark, E.M. Implications of slab mineralogy for subduction dynamics. Phys. Earth Planet. Inter. 2001, 127, 51-66. [CrossRef]

33. Wiens, D.A. Seismological constraints on the mechanism of deep earthquakes: Temperature dependence of deep earthquake source properties. Phys. Earth Planet. Inter. 2001, 127, 145-163. [CrossRef]

34. Bina, C.R.; Kawakatsu, H. Buoyancy, bending, and seismic visibility in deep slab stagnation. Phys. Earth Planet. Inter. 2010, 183, 330-340. [CrossRef]

35. Agrusta, R.; Hunen, J.; Goes, S. The effect of metastable pyroxene on the slab dynamics. Geophys. Res. Lett. 2014, 41, 8800-8808. [CrossRef]

36. King, S.D.; Frost, D.J.; Rubie, D.C. Why cold slabs stagnate in the transition zone. Geology 2015, 43, $231-234$. [CrossRef] 
37. Akella, J.; Winkler, H.G. Orthorhombic amphibole in some metamorphic reactions. Contrib. Mineral. Petrol. 1966, 12, 1-12. [CrossRef]

38. Inoue, T.; Irifune, T.; Yurimoto, H.; Miyagi, I. Decomposition of K-amphibole at high pressures and implications for subduction zone volcanism. Phys. Earth Planet. Inter. 1998, 107, 221-231. [CrossRef]

39. Trønnes, R. Stability range and decomposition of potassic richterite and phlogopite end members at 5-15 GPa. Mineral. Petrol. 2002, 74, 129-148. [CrossRef]

40. Comboni, D.; Lotti, P.; Gatta, G.D.; Merlini, M.; Liermann, H.P.; Frost, D.J. Pargasite at high pressure and temperature. Phys. Chem. Miner. 2018, 45, 259-278. [CrossRef]

41. Mandler, B.E.; Grove, T.L. Controls on the stability and composition of amphibole in the Earth's mantle. Contrib. Mineral. Petrol. 2016, 171, 68. [CrossRef]

42. Yamasaki, T.; Seno, T. Double seismic zone and dehydration embrittlement of the subducting slab. J. Geophys. Res.: Solid Earth 2003, 108, 2212. [CrossRef]

43. Poli, S.; Schmidt, M.W. Petrology of subducted slabs. Annu. Rev. Earth Planet. Sci. 2002, 30, $207-235$. [CrossRef]

44. Green, H.W.; Zhou, Y. Transformation-induced faulting requires an exothermic reaction and explains the cessation of earthquakes at the base of the mantle transition zone. Tectonophysics 1996, 256, 39-56. [CrossRef]

45. Kirby, S.H.; Stein, S.; Okal, E.A.; Rubie, D.C. Metastable mantle phase transformations and deep earthquakes in subducting oceanic lithosphere. Rev. Geophys. 1996, 34, 261-306. [CrossRef]

46. Ganguly, J.; Freed, A.M.; Saxena, S.K. Density profiles of oceanic slabs and surrounding mantle: Integrated thermodynamic and thermal modeling, and implications for the fate of slabs at the $660 \mathrm{~km}$ discontinuity. Phys. Earth Planet. Inter. 2009, 172, 257-267. [CrossRef]

47. Raleigh, C.B. Tectonic implications of serpentinite weakening. Geophys. J. Int. 1967, 14, 113-118. [CrossRef]

48. Raleigh, C.B.; Paterson, M.S. Experimental deformation of serpentinite and its tectonic implications. J. Geophys. Res. 1965, 70, 3965-3985. [CrossRef]

49. Green, H.W.; Houston, H. The mechanics of deep earthquakes. Annu. Rev. Earth Planet. Sci. 1995, 23, 169-213. [CrossRef]

50. Kirby, S. Interslab earthquakes and phase changes in subducting lithosphere. Rev. Geophys. 1995, 33, $287-297$. [CrossRef]

51. Peacock, S.M. Are the lower planes of double seismic zones caused by serpentine dehydration in subducting oceanic mantle? Geology 2001, 29, 299-302. [CrossRef]

52. Hacker, B.R.; Peacock, S.M.; Abers, G.A.; Holloway, S.D. Subduction factory 2. Are intermediate-depth earthquakes in subducting slabs linked to metamorphic dehydration reactions? J. Geophys. Res.: Solid Earth 2003, 108, 2030. [CrossRef]

53. Jung, H.; Green, H.W., II; Dobrzhinetskaya, L.F. Intermediate-depth earthquake faulting by dehydration embrittlement with negative volume change. Nature 2004, 428, 545. [CrossRef] [PubMed]

54. Zahradník, J.; Čížková, H.; Bina, C.R.; Sokos, E.; Janský, J.; Tavera, H.; Carvalho, J. A recent deep earthquake doublet in light of long-term evolution of Nazca subduction. Sci. Rep. 2017, 7, 45153. [CrossRef] [PubMed]

55. Davidson, J.; Turner, S.; Handley, H.; Macpherson, C.; Dosseto, A. Amphibole "sponge" in arc crust? Geology 2007, 35, 787-790. [CrossRef]

56. Wunder, B.; Wirth, R.; Gottschalk, M. Antigorite pressure and temperature dependence of polysomatism and water content. Eur. J. Mineral. 2001, 13, 485-496. [CrossRef]

57. Carlson, R.L.; Miller, D.J. Mantle wedge water contents estimated from seismic velocities in partially serpentinized peridotites. Geophys. Res. Lett. 2003, 30, 1250. [CrossRef]

58. Green, H.; Shi, F.; Bozhilov, K.; Xia, G.; Reches, Z. Phase transformation and nanometric flow cause extreme weakening during fault slip. Nat. Geosci. 2015, 8, 484-489. [CrossRef]

59. Hacker, B.R.; Christie, J.M. Brittle/ductile and plastic/cataclastic transitions in experimentally deformed and metamorphosed amphibolite. Geophys. Monogr. 1990, 56, 127-147.

60. Konrad-Schmolke, M.; Halama, R.; Wirth, R.; Thomen, A.; Klitscher, N.; Morales, L.; Schreiber, A.; Wilke, F.D.H. Mineral dissolution and reprecipitation mediated by an amorphous phase. Nat. Commun. 2018, 9, 1637. [CrossRef] 
61. Ferrand, T.P.; Hilairet, N.; Incel, S.; Deldicque, D.; Labrousse, L.; Gasc, J.; Renner, J.; Wang, Y.; Green, H.W.; Schubnel, A. Dehydration-driven stress transfer triggers intermediate-depth earthquakes. Nat. Commun. 2017, 8, 15247. [CrossRef]

62. Yong, T.; Dera, P.; Zhang, D. Single-crystal X-ray diffraction of grunerite up to 25.6 GPa: A new high-pressure clinoamphibole polymorph. Phys. Chem. Miner. 2019, 46, 215-227.

(C) 2019 by the authors. Licensee MDPI, Basel, Switzerland. This article is an open access article distributed under the terms and conditions of the Creative Commons Attribution (CC BY) license (http://creativecommons.org/licenses/by/4.0/). 